Article

\title{
Simultaneous Determination of Daidzein, Genistein and Formononetin in Coffee by Capillary Zone Electrophoresis
}

\author{
Feng Luan*, Li Li Tang, Xuan Xuan Chen and Hui Tao Liu \\ College of Chemistry and Chemical Engineering, Yantai University, Yantai 264005, China; \\ tlili0216@sina.com (L.L.T.); xxchen_95@sina.com (X.X.C.); liuht-ytu@163.com (H.T.L.) \\ * Correspondence: fluan@sina.com; Tel.: +86-535-6902063 \\ Academic Editor: Doo Soo Chung \\ Received: 29 October 2016; Accepted: 20 December 2016; Published: 1 January 2017
}

\begin{abstract}
Coffee is a favorite and beverage in Western countries that is consumed daily. In the present study, capillary zone electrophoresis (CE) was applied for the separation and quantification of three isoflavones including daidzein, genistein and formononetin in coffee. Extraction of isoflavones from the coffee sample was carried out by extraction and purification process using ether after the acid hydrolysis with the antioxidant butylated hydroxy-toluene (BHT). The experimental conditions of the CE separation method were: $20 \mathrm{mmol} / \mathrm{L} \mathrm{Na}_{2} \mathrm{HPO}_{4}$ buffer solution, $25 \mathrm{kV}$ applied voltage, $3 \mathrm{~s}$ hydrodynamic injection at $30 \mathrm{mbar}$, and UV detection at $254 \mathrm{~nm}$. The results show that the three compounds can be tested within $10 \mathrm{~min}$ with a linearity of $0.5-50 \mu \mathrm{g} / \mathrm{mL}$ for all three compounds. The limits of detection were $0.0642,0.134$, and $0.0825 \mu \mathrm{g} / \mathrm{mL}$ for daidzein, formononetin and genistein, respectively. The corresponding average recovery was $99.39 \%$ (Relative Standard Detection $(\mathrm{RSD})=1.76 \%), 98.71 \%(\mathrm{RSD}=2.11 \%)$ and $97.37 \%(\mathrm{RSD}=3.74 \%)$.
\end{abstract}

Keywords: capillary zone electrophoresis (CE); daidzein; genistein; formononetin; acid hydrolysis

\section{Introduction}

Phytoestrogens (PEs), also called "dietary estrogens", are a group of natural, non-steroidal, estrogen-like compounds found in a wide variety of plants consumed by humans [1]. Currently, four different groups of plant phenolics are considered PEs, including isoflavones and lignans, coumestanes, flavonoids and stilbenes. Other less-investigated compounds include prenylflavonoids, flavones, flavans and phytosterol esters [2]. These compounds are similar to $17 \beta$-estradiol in structure and function [3]. They have a dual-directional regulation function in the human body, meaning both anti-estrogen activity and estrogenic activity [4]. Such compounds have good curative effects for the treatment of cardiovascular disease, breast cancer, Alzheimer's disease, neurodegenerative disorders, and osteoporosis, etc. [5-8]. They can also be used for the treatment of the symptoms of menopause [9].

PEs are common in nature and have many pharmacological activities $[9,10]$. It has been reported that the daily take of PEs for menopausal women in the Caucasus region of the United States is no more than one milligram [11]. There are some foods that contain PEs including: soybeans and soy products, tempeh, linseeds, sesame seeds, wheat berries, fenugreek, oats, barley, beans, lentils, yams, rice, alfalfa, mung beans, apples, carrots, pomegranates [12], wheat germ, rice bran, lupin, kudzu, coffee, licorice root, mint, ginseng, hops [13], bourbon, beer [14], fennel and anise [15]. As we know, the content of PEs is different between various foods. In addition, it may also occur in the same kinds of foods, such as soy beverages and tofu, since they are made of different kinds of raw materials or using different processing methods [16].

It has been proved that phytoestrogen-rich diets include soybeans and soybean products, followed by legumes, nuts, oilseeds, fruits and vegetables [17]. As is well known, there is a phenomenon 
where people consume less soy and its derivatives in Western countries than in Eastern ones [18]. However, coffee is a favorite beverage in Western countries that is consumed daily; for example, in the United States, 29 September is celebrated as "National Coffee Day" [19]. Thus, it is necessary to study the content of isoflavones in coffee.

Some researchers have been studied the phytoestrogens in plants [20]. The methods used for the determination of phytoestrogens in plants are GC-MS [21,22], HPLC [17,23-31], and LC-MS [32,33]. It should be noted that HPLC separation is generally carried out on reversed-phase columns using the methanol of acetonitrile and water containing small amounts of acid as a modifier [29]. As far as we know, few studies have been reported using capillary zone electrophoresis (CE) in the analysis of isoflavones. Aramendia et al. [34] separated and identified several isoflavones using CE-ESI/MS in negative ion mode from standard samples. García-Villalba et al. [35] used capillary electrophoresis-time-of-flight-mass spectrometry to compare the metabolic profiles of conventional and genetically modified soybeans, including isoflavones, amino acids, carboxylic acids and peptides. In the above references, separation was carried out in positive mode at $\mathrm{pH}$ 9-9.5 and detection was achieved in negative ionization mode, but quantification was not reported. Also, the process is somewhat time-consuming, though it is useful and effective.

From the works reported so far, one can see that the quantitative determination of isoflavones in plants is mostly done by HPLC combined with acid hydrolysis or alcohol extraction. In addition, the separation system is acidic. The HPLC method uses a large amount of organic solvent in mobile phase and requires a long separation time. The acid hydrolysis and ethanol extraction are simple; however, the process cannot transform glycosides into aglycone. Also, the acid hydrolysis process may lead to the samples containing a large number of complexes and it is difficult to separate substances after they are treated by acid hydrolysis.

The aim of this work was to develop a simple, efficient and sensitive CE method, as an alternative to other methods, for the quantitative analysis of three isoflavones, including daidzein, genistein and formononetin (their chemical structures are shown in Figure 1) in coffee. For this, we improved the extraction method of isoflavones from the coffee sample with an extraction and purification process using ether instead of ethanol after the process of acid hydrolysis with the antioxidant butylated hydroxy-toluene (BHT). The proposed method was successfully applied to the determination of three isoflavones in commercially available coffee samples. To our knowledge, there are no methods that describe the quantification of isoflavones in coffee samples using the single CE. Also, the sample preparation of this method is simple, the analytical time is shorter, and the comparative cost is relatively lower. It can be used as an alternative method for the determination of isoflavones in coffee.<smiles>COc1ccc(-c2coc3cc(O)ccc3c2=O)cc1</smiles>

(a) Formononetin

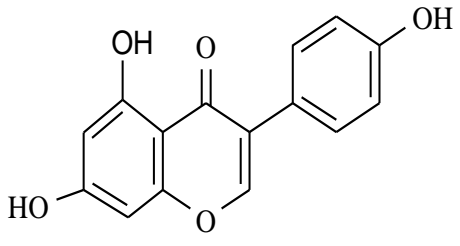

(b) Genistein<smiles>O=c1c(-c2ccc(O)cc2)coc2cc(O)ccc12</smiles>

(c) Daidzein

Figure 1. The chemical structures of (a) formononetin, (b) genistein, and (c) daidzein.

\section{Materials and Methods}

\subsection{Chemicals and Reagents}

Isoflavone standards daidzein $(\geq 98 \%)$, genistein $(\geq 98 \%)$ and formononetin $(\geq 98 \%)$ were purchased from Shanghai Juyuan Biological Technology Co., Ltd. (Shanghai, China). Disodium hydrogen phosphate $\left(\mathrm{Na}_{2} \mathrm{HPO}_{4}\right)$ was obtained from Sinopharm Chemical Reagent Co., Ltd. (Shanghai, China). Methanol, acetonitrile were obtained from Kemel Chemical Reagent Co., Ltd. (Tianjin, China). 
Butylated hydroxy-toluene (BHT) was used as antioxidant and was obtained from Shanghai Feige Chemical Co. Ltd. (Shanghai, China). The analytical grade regents were used to prepare the samples and the buffer solutions. The water used in all studies was ultrapure water $(18.25 \mathrm{M} \Omega \cdot \mathrm{cm})$ obtained from an ultrapure purification system (Yongjieda, Hangzhou, China). The nitrogen used for evaporation of solvents was of $99.9 \%$ purity and supplied by Feiyuan Comprehensive Service Technology (Yantai, China).

\subsection{Standard and Sample Preparation}

Each type of isoflavone stock solution $(1 \mathrm{~g} / \mathrm{L})$ was prepared in methanol and stored at $-18{ }^{\circ} \mathrm{C}$ in volumetric flask. A series of calibration solutions $(0.5,1.0,5.0,10.0$ and $50.0 \mu \mathrm{g} / \mathrm{mL})$ was prepared by diluting the stock standard solution with methanol and stored at $4{ }^{\circ} \mathrm{C}$.

Ground coffee, purchased from the local supermarket of United States of America, was passed through a $0.45 \mathrm{~mm}$ sieve. A $0.2 \mathrm{~g}$ aliquot of ground coffee was spiked with the antioxidant $(1 \%, 50 \mu \mathrm{L})$, ethanol $(2 \mathrm{~mL})$ and hydrochloric acid $3.4 \mathrm{~mol} / \mathrm{L} \mathrm{HCL}(2 \mathrm{~mL})$. The acid hydrolysis was performed at $75^{\circ} \mathrm{C}$ for $150 \mathrm{~min}$, under reflux. This process was performed according to Alves et al. [23] with minor modification. After the hydrolysis, $1 \mathrm{~mL}$ of the hydrolysate was neutralized with $120 \mu \mathrm{L}$ of sodium hydroxide ( $10 \mathrm{~mol} / \mathrm{L})$, vortexed and ultra-centrifuged ( $5000 \mathrm{r} / \mathrm{min}, 5 \mathrm{~min})$. Then $2 \mathrm{~mL}$ supernatant was collected, extracted and purified by ether [36]. Then the superstratum ether was dried by nitrogen. The residue was dissolved in methanol, and volume was completed till $2 \mathrm{~mL}$. And then it was filtered through a $0.45 \mu \mathrm{m}$ Millipore filters before analysis and stored under refrigeration $\left(4^{\circ} \mathrm{C}\right)$ until use.

\subsection{CE Apparatus}

In present study, the experiments were performed on a LUMEX CAPEL 105M Capillary Electrophoresis System (LUMEX Ltd., St. Peterburg, Russia). A $60 \mathrm{~cm}$ (50.5 cm effective length), $75 \mu \mathrm{m}$ i.d. fused silica capillary (Yongnian Ruifeng Chromatographic Devices Limited Company, Baoding, China) was used. A PH5500 dual-channel pH/ion meter (Crison, Singapore) was used for regulating the $\mathrm{pH}$ of the buffers.

\subsection{Electrophoretic Conditions}

Before using, each new capillary column was rinsed sequentially with ultrapure water for $10 \mathrm{~min}$, $0.5 \mathrm{~mol} / \mathrm{L} \mathrm{NaOH}$ for $40 \mathrm{~min}$, and then ultrapure water for $10 \mathrm{~min}$. At the beginning of each day the capillary was rinsed with ultrapure water for $2 \mathrm{~min}, 0.2 \mathrm{~mol} / \mathrm{L} \mathrm{NaOH}$ for $10 \mathrm{~min}$, ultrapure water for $5 \mathrm{~min}$ and running buffer for 10min. Between different buffers, the capillary was conditioned with ultrapure water for $2 \mathrm{~min}, 0.2 \mathrm{~mol} / \mathrm{L} \mathrm{NaOH}$ for $10 \mathrm{~min}$, ultrapure water for $5 \mathrm{~min}$, and buffer for $5 \mathrm{~min}$. The capillary was conditioned only with running buffer for $3 \mathrm{~min}$ between consecutive injections. All buffers and solutions were filtered through a $0.45 \mu \mathrm{m}$ Millipore filter before injection. Pressure injection was set at $30 \mathrm{mbar}$ for $3 \mathrm{~s}$. The conditions of electrophoresis was kept the temperature at $25^{\circ} \mathrm{C}$, applied voltage at $25 \mathrm{kV}$, and the UV detection at $254 \mathrm{~nm}$.

\section{Results and Discussion}

\subsection{Optimization of the CE Method}

It was necessary to determine the parameters of CE before analyzing the daidzein, genistein and formononetin in the coffee sample. The UV detection wavelength of isoflavones is generally 250-265 nm. In order to determine the optimal wavelength for simultaneous determination of the three compounds, the UV absorption spectrum of the isoflavone solution from 230 to $350 \mathrm{~nm}$ was scanned (see Figure 2). As can be seen from the figure, the best absorption wavelengths of the three compounds were $250-260 \mathrm{~nm}, 250-260 \mathrm{~nm}$, and 260-270 nm, respectively. However, all three isoflavones have a strong absorption at $254 \mathrm{~nm}$, so the detection wavelength was set to $254 \mathrm{~nm}$. 


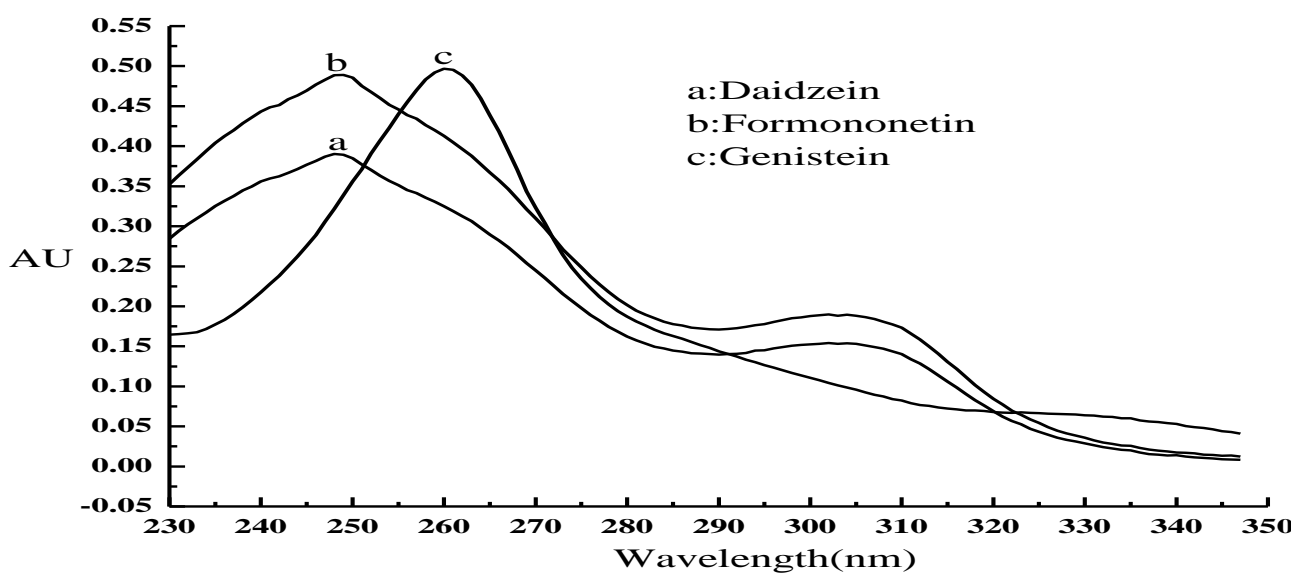

Figure 2. UV spectra of formononetin, daidzein and genistein.

Five different concentrations of $\mathrm{Na}_{2} \mathrm{HPO}_{4}$ solution at 10, 20, 30, 40 and $50 \mathrm{mmol} / \mathrm{L}$ were investigated in the present study. With the buffer solution concentration increased, the degree of separation improved, and at the same time the analysis time increased as well. However, the analysis time of $30 \mathrm{mmol} / \mathrm{L}$ was a little shorter than that of $20 \mathrm{mmol} / \mathrm{L}$. So, a buffer concentration of $30 \mathrm{mmol} / \mathrm{L}$ buffer concentration was selected.

The buffer $\mathrm{pH}$ may have some effect on the migration. Using the above optimized buffer concentration $\left(30 \mathrm{mmol} / \mathrm{L} \mathrm{Na}_{2} \mathrm{HPO}_{4}\right)$, the $\mathrm{pH}$ was regulated at 7.0, 8.0, 9.0, 10.0, 11.0. As the $\mathrm{pH}$ increased, the analytical time increased; however, the separation was still not ideal. It was almost the same as that of the basic $30 \mathrm{mmol} / \mathrm{L} \mathrm{Na}_{2} \mathrm{HPO}_{4}$. So the basic system without regulating the $\mathrm{pH}$ value was used in the analysis.

In the following, three organic modifiers (methanol, acetonitrile and acetone) were added to $30 \mathrm{mmol} / \mathrm{L} \mathrm{Na}_{2} \mathrm{HPO}_{4}$ at $\mathrm{pH}=9.9$ to investigate the influence of the separations, respectively. From the results, we can see that their presence leads to no obvious improvement in the peak shape. Therefore, none of the organic modifiers was added to the separation system.

The effects of an injection time of 1,3, 5, 8 and $10 \mathrm{~s}$ at 30 mbar were also investigated in order to obtain a better sensitivity and peak shape; finally, $3 \mathrm{~s}$ proved to be ideal for the subsequent analysis. Similarly, effects of temperature (in the range of $15-25^{\circ} \mathrm{C}$ ) and applied voltage (in the range of $15-25 \mathrm{kV}$ ) on the separation efficiencies were also verified. Finally, a temperature of $25^{\circ} \mathrm{C}$ and an applied voltage of $25 \mathrm{kV}$ were selected.

From the above results, the optimal CE separation conditions were selected: $30 \mathrm{mM} \mathrm{Na}_{2} \mathrm{HPO}_{4}$, $3 \mathrm{~s}$ pressure injection at $30 \mathrm{mbar}, 25 \mathrm{kV}$ applied voltage at $25^{\circ} \mathrm{C}$ and detection at $254 \mathrm{~nm}$. Under these conditions, the electropherogram of daidzein, genistein and formononetin was obtained and is shown in Figure 3.

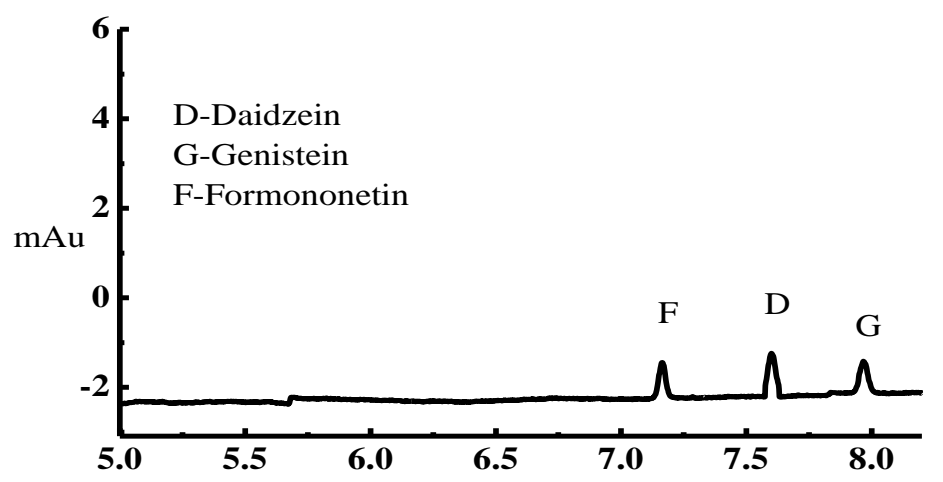

Figure 3. Electropherogram of the standard mixture of formononetin, daidzein and genistein. 


\subsection{Validation of the CE Method}

\subsubsection{Linearity, Limit of Detection and Limit of Quantification}

The linear ranges were tested at $0.5-50.0 \mu \mathrm{g} / \mathrm{mL}$ for the three isoflavones at five concentration levels. Calibration curves were obtained by plotting the peak area of each standard as a function of the standard concentration (C). The correlations were: $y=4.0245 C+2.3062\left(R^{2}=0.9995\right)$ for formononetin; $y=8.4133 C-2.8224\left(R^{2}=0.9998\right)$ for daidzein; $y=6.5477 C-1.3905\left(R^{2}=0.9994\right)$ for genistein. The limit of detection (LOD) and limit of quantification (LOQ) were determined as $3 \mathrm{\sigma} / \mathrm{s}$ and $10 \sigma / \mathrm{s}$, respectively, where $\sigma$ is the standard deviation of the blank responses and $\mathrm{s}$ is the slope of the calibration curve. The LODs of formononetin, daidzein and genistein were $0.134,0.0642$ and $0.0825 \mu \mathrm{g} / \mathrm{mL}$, respectively. The LOQs were $0.446 \mu \mathrm{g} / \mathrm{mL}$ for formononetin, $0.214 \mu \mathrm{g} / \mathrm{mL}$ for daidzein, and $0.275 \mu \mathrm{g} / \mathrm{mL}$ for genistein.

\subsubsection{Study of Precision and Accuracy}

The precision of the proposed method was validated by the intra-day and inter-day values of the migration time and peak area under the optimal conditions. The intra-day repeatability was determined by replicating injections of a $10 \mu \mathrm{g} / \mathrm{mL}$ solution of isoflavones six times in one day, while the inter-day repeatability was determined by performing injections for six consecutive days. The results are listed in Table 1 . As can be seen in the table, the relative standard deviation (RSD) was less than $1.6 \%$ for the migration time and less than $5.4 \%$ for the peak area in all cases.

Table 1. Intra-day and inter-day precision of migration time and peak area for isoflavones.

\begin{tabular}{ccccc}
\hline \multirow{2}{*}{ Compound } & \multicolumn{2}{c}{ Intra-Day (\%) } & \multicolumn{2}{c}{ Inter-Day (\%) } \\
\cline { 2 - 5 } & Migration Time & Peak Area & Migration Time & Peak Area \\
\hline Formononetin & 0.34 & 4.60 & 0.55 & 5.31 \\
Daidzein & 0.62 & 3.45 & 1.23 & 4.51 \\
Genistein & 1.03 & 4.29 & 1.52 & 5.01 \\
\hline
\end{tabular}

The method's accuracy was evaluated by the standard addition procedure. Firstly, blank samples were analyzed in order to determine the actual content of the three isoflavones in the sample. Then, three different amounts $(0.5 \mu \mathrm{g} / \mathrm{mL}, 1.0 \mu \mathrm{g} / \mathrm{mL}$ and $2.0 \mu \mathrm{g} / \mathrm{mL})$ of isoflavones were added into three coffee samples before the extraction. The results are presented in Table 2. From the table, we can see that satisfactory average recoveries (97.37\%-99.39\%) were obtained with an RSD lower than 3.74\%. These data show that the pretreatment method has good extraction efficiency.

Table 2. Recoveries for the determination of the three isoflavones in coffee.

\begin{tabular}{cccc}
\hline Compound & $\begin{array}{c}\text { Concentration Added } \\
(\boldsymbol{\mu g} / \mathbf{m L})\end{array}$ & $\begin{array}{c}\text { Recovery } \\
(\mathbf{\%}, \boldsymbol{n}=\mathbf{3})\end{array}$ & $\begin{array}{c}\text { RSD } \\
(\mathbf{\%})\end{array}$ \\
\hline \multirow{3}{*}{ Formononetin } & 0.5 & 105.20 & \\
& 1.0 & 95.53 & 1.76 \\
\hline \multirow{2}{*}{ Daidzein } & 2.0 & 97.44 & \\
& 0.5 & 92.31 & \\
& 1.0 & 103.34 & 2.11 \\
Genistein & 2.0 & 100.48 & \\
& 0.5 & 103.58 & \\
& 1.0 & 90.87 & 3.74 \\
\hline
\end{tabular}




\subsection{Optimization of the Extraction Conditions and Sample Analysis}

Pretreatment process optimization has to be developed since the isoflavones occur mainly as glycosides present in the coffee $[37,38]$. For the purpose of detecting the total amount of aglycones, the acid procedure is usually performed. According to Alves et al. [23], acid hydrolysis was performed first in the present study. However, it cannot give an ideal detection using the same procedure as in the reference. So we extracted and purified the sample with ether [36] after the process of acid hydrolysis with the antioxidant butylated hydroxy-toluene (BHT). The electropherograms of the coffee samples are shown in Figure 4. From the figure, one can see that the daidzein can be detected and at a value of $0.012 \mathrm{mg} / \mathrm{g}$. Compared with the results of the work of Alves et al. [23], we can see that the amount of daidzein found in this study is in accordance with the value reported by the HPLC method. The work of Kuhnle et al. [31] reported total isoflavones of $1 \mathrm{mg}$ per $100 \mathrm{~g}$ of instant coffee which is also similar to our results. The other two isoflavones could not be detected in our study. The reason may be that different kinds of coffee may contain different quantities or kinds of isoflavones [23], or the contents of the two could not be detected for this particular sample. There are other works $[21,39]$ that have detected the coffee beverage ( 1 ìg of isoflavones per cup of coffee beverage $(287 \mathrm{~mL})$ ) and coffee brew (10-66 ìg of daidzein, 15-29 ìg of genistein, and 72-78 ìg of formononetin for a $100 \mathrm{~g}$ cup of coffee brew) values, which indicated our results are acceptable.

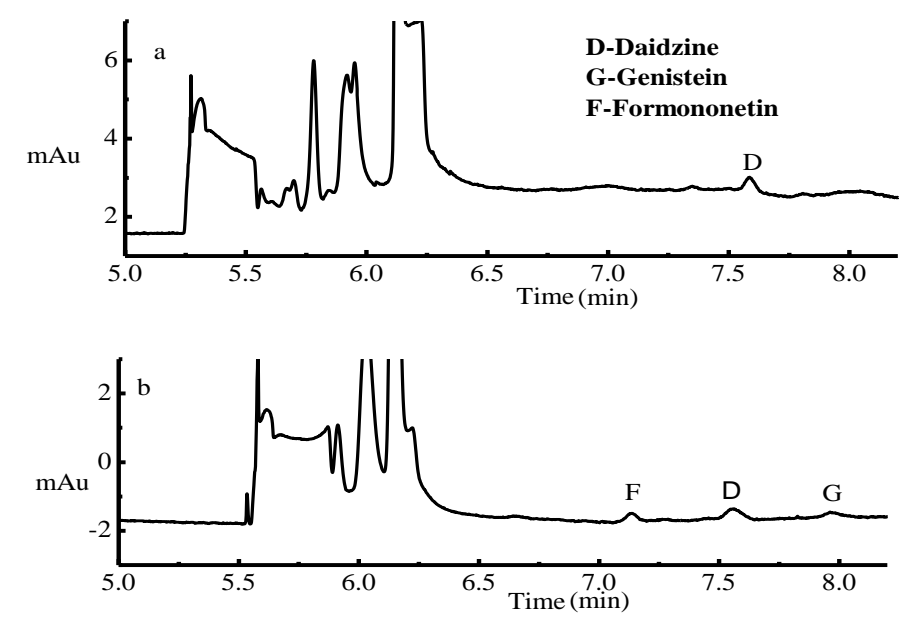

Figure 4. Electropherograms of (a) coffee sample; (b) coffee sample spiked with $1.0 \mu \mathrm{g} / \mathrm{mL}$ three isoflavones.

\section{Conclusions}

This work presents the application of $\mathrm{CE}$ for the determination of daidzein, genistein and formononetin in coffee. This method has the advantages of high sensitivity, shorter analytical time, minor amounts of samples and simple operation. It is concluded that the CE method is a good alternative to other methods.

Acknowledgments: This work was financially supported by the National Natural Science Foundation of China (No. 21675138).

Author Contributions: Feng Luan and Huitao Liu conceived and designed the experiments; Xuanxuan Chen and Lili Tang performed the experiments; Feng Luan and Xuanxuan Chen wrote the paper.

Conflicts of Interest: The authors confirm that this article content has no conflict of interest.

\section{References}

1. Breithofer, A.; Graumann, K.; Scicchitano, M.S.; Karathanasis, S.K.; Butt, T.R.; Jungbauer, A. Regulation of human estrogen receptor by phytoestrogens in yeast and human cells. J. Steroid Biochem. Mol. Biol. 1998, 67, 421-429. [CrossRef] 
2. Mueller, S.O. Overview of in vitro tools to assess the estrogenic and antiestrogenic activity of phytoestrogens. J. Chromatogr. B 2002, 777, 155-165. [CrossRef]

3. Kuhnle, G.G.; Dell'aquila, C.; Low, Y.L.; Kussmaul, M.; Bingham, S.A. Extraction and quantification of phytoestrogens in foods using automated solid-phase extraction and LC/MS/MS. Anal. Chem. 2007, 79, 9234-9239. [CrossRef] [PubMed]

4. Ososki, A.L.; Kennelly, E.J. Phytoestrogens: A review of the present state of research. Phytother. Res. 2003, 17, 845-869. [CrossRef] [PubMed]

5. Nelson, H.D.; Humphrey, L.L.; Nygren, P.; Teutsch, M.; Allan, S.; Jama, J.D. Effects of estrogen plus progestin on risk of fracture and bone mineral density. J. Am. Med. Assoc. 2002, 288, 872-881. [CrossRef]

6. Tsuang, Y.H.; Chen, L.T.; Chiang, C.J.; Wu, L.C.; Chiang, Y.F.; Chen, P.Y.; Sun, J.S.; Wang, C.C. Isoflavones prevent bone loss following ovariectomy in youth adult rats. J. Orthop. Surg. Res. 2008, 3, 1-9. [CrossRef] [PubMed]

7. Siow, R.C.; Li, F.Y.; Rowlands, D.J.; de Winter, P.; Mann, G.E. Cardiovascular targets for estrogens and phytoestrogens: Transcriptional regulation of nitric oxide synthase and antioxidant defense genes. Free Radic. Biol. Med. 2007, 42, 909-925. [CrossRef] [PubMed]

8. Brann, D.W.; Dhandapani, K.; Wakade, C.; Mahesh, V.B.; Khan, M.M. Neurotrophic and neuroprotective actions of estrogen: Basic mechanisms and clinical implications. Steroids 2007, 72, 381-405. [CrossRef] [PubMed]

9. Reinli, K.; Block, G. Phytoestrogen content of foods-A compendium of literature values. Nutr. Cancer 1996, 26, 123-148. [CrossRef] [PubMed]

10. Cassidy, A.; Hanley, B.; Lamuela-Raventos, R.M. Isoflavones, lignans and stilbenes-origins, metabolism and potential importance to human health. J. Sci. Food Agric. 2000, 80, 1044-1062. [CrossRef]

11. De Kleijn, M.J.; van der Schouw, Y.T.; Wilson, P.W.; Adlercreutz, H.; Mazur, W.; Grobbee, D.E.; Jacques, P.F. Intake of dietary phytoestrogens is low in postmenopausal women in the United States: The Framingham Study (1-4). J. Nutr. 2001, 131, 1826-1832. [PubMed]

12. Van Elswijk, D.A.; Schobel, U.P.; Lansky, E.P.; Irth, H.; van der Greef, J. Rapid dereplication of estrogenic compounds in pomegranate (Punica granatum) using on-line biochemical detection coupled to mass spectrometry. Phytochemistry 2004, 65, 233-241. [CrossRef] [PubMed]

13. Chadwick, L.R.; Nikolic, D.; Burdette, J.E.; Overk, C.R.; Bolton, J.L.; van Breemen, R.B.; Fröhlich, R.; Fong, H.H.; Farnsworth, N.R.; Pauli, G.F. Estrogens and congeners from Spent Hops (Humulus lupulus). J. Nat. Prod. 2004, 67, 2024-2032. [CrossRef] [PubMed]

14. Rosenblum, E.R.; Stauber, R.E.; Van Thiel, D.H.; Campbell, I.M.; Gavaler, J.S. Assessment of the estrogenic activity of phytoestrogens isolated from bourbon and beer. Alcohol. Clin. Exp. 1993, 17, 1207-1209. [CrossRef]

15. Albert-Puleo, M. Fennel and anise as estrogenic agents. J. Ethnopharmacol. 1980, 2, 337-344. [CrossRef]

16. Dewell, A. Effects of Phytoestrogens on Lipids in Hypercholestrolemic Postmenopausal Women. Master's Thesis, San Jose State University, San Jose, CA, USA, December 2001.

17. Yanaka, K.; Takebayashi, J.; Matsumoto, T.; Ishimi, Y. Determination of 15 isoflavone isomers in soy foods and supplements by high-performance liquid chromatography. J. Agric. Food. Chem. 2012, 60, 4012-4016. [CrossRef] [PubMed]

18. Adlercreutz, H.; Hämäläinen, E.; Gorbach, S.; Goldin, B. Dietary phyto-oestrogens and the menopause in Japan. Lancet 1992, 339, 1233-1234. [CrossRef]

19. CBS News. National Coffee Day: Do You Know What's in Your Joe? Available online: http:/ / www.cbsnews.com (accessed on 29 September 2016).

20. Vacek, J.; Klejdus, B.; Lojkova, L.; Kubán, V. Current trends in isolation, separation, determination and identification of isoflavones: A review. J. Sep. Sci. 2008, 31, 2054-2067. [CrossRef] [PubMed]

21. Mazur, W.; Wähälä, K.; Rasku, S.; Makkonen, A.; Hase, T.; Adlercreutz, H. Lignans and isoflavonoid polyphenols in tea and coffee. J. Med. Food 1999, 2, 199-202. [CrossRef] [PubMed]

22. Bonzanini, F.; Bruni, R.; Palla, G.; Serlataite, N.; Caligiani, A. Identification and distribution of lignans in Punica granatum L. fruit endocarp, pulp, seeds, wood knots and commercial juices by GC-MS. Food Chem. 2009, 117, 745-749. [CrossRef]

23. Alves, R.C.; Almeida, I.M.C.; Casal, S.; Oliveira, M.B.P.P. Method development and validation for isoflavones quantification in coffee. Food Chem. 2010, 122, 914-919. [CrossRef]

24. Peñalvo, J.L.; Nurmi, T.; Adlercreutz, H. A simplified HPLC method for total isoflavones in soy products. Food Chem. 2004, 87, 297-305. [CrossRef] 
25. Apers, S.; Naessens, T.; Van Den Steen, K.; Cuyckens, F.; Claeys, M.; Pieters, L.; Vlietinck, A. Fast high-performance liquid chromatography method for quality control of soy extracts. J. Chromatogr. B 2004, 1038, 107-112. [CrossRef]

26. Ha, H.; Lee, Y.S.; Lee, J.H.; Choi, H.; Kim, C. High performance liquid chromatographic analysis of isoflavones in medicinal herbs. Arch. Pharm. Res. 2006, 29, 96-101. [CrossRef] [PubMed]

27. Cherdshewasart, W.; Subtang, S.; Dahlan, W. Major isoflavonoid contents of the phytoestrogen rich-herb Pueraria mirifica in comparison with Pueraria lobata. J. Pharm. Biomed. Anal. 2007, 43, 428-434. [CrossRef] [PubMed]

28. Ramos, G.P.; Dias, P.M.B.; Morais, C.B.; Fröehlich, P.E.; Dall'Agnol, M.; Zuanazzi, J.A. LC determination of four isoflavone aglycones in red clover (Trifolium pratense L.). Chromatographia 2008, 67, 125-129. [CrossRef]

29. Matsumoto, D.; Kotani, A.; Hakamata, H.; Takahashi, K.; Kusu, F. Column switching high-performance liquid chromatography with two channels electrochemical detection for high-sensitive determination of isoflavones. J. Chromatogr. A 2010, 1217, 2986-2989. [CrossRef] [PubMed]

30. Shen, D.; Wu, Q.; Sciarappa, W.J.; Simon, J.E. Chromatographic fingerprints and quantitative analysis of isoflavones in tofu-type soybeans. Food Chem. 2012, 130, 1003-1009. [CrossRef]

31. Kuhnle, G.G.C.; Dell'Aquila, C.; Aspinall, S.M.; Runswick, S.A.; Mulligan, A.A.; Bingham, S.A. Phytoestrogen content of beverages, nuts, seeds, and oils. J. Agric. Food Chem. 2008, 56, 7311-7315. [CrossRef] [PubMed]

32. Prasain, J.K.; Arabshahi, A.; Moore, D., II; Greendale, G.A.; Wyss, J.M.; Barnes, S. Simultaneous determination of 11 phytoestrogens in human serum using a 2 min liquid chromatography/tandem mass spectrometry method. J. Chromatogr. B 2010, 878, 994-1002. [CrossRef] [PubMed]

33. Zhang, J.X.; Guan, S.H.; Yang, M.; Feng, R.H.; Wang, Y.; Zhang, Y.B.; Guo, D.A. Simultaneous determination of 24 constituents in Cortex Lycii using high-performance liquid chromatography-triple quadrupole mass spectrometry. J. Pharm. Biomed. Anal. 2013, 77, 63-70. [CrossRef] [PubMed]

34. Aramendia, M.A.; Garcia, I.; Lafont, F.; Marinas, J.M. Determination of isoflavones using capillary electrophoresis in combination with electrospray mass spectrometry. J. Chromatogr. A 1995, 707, 327-333. [CrossRef]

35. García-Villalba, R.; León, C.; Dinelli, G.; Segura-Carretero, A.; Fernández-Gutiérrez, A.; Garcia-Cañas, V.; Cifuentes, A. Transgenic vs. conventional soybean: A comparative metabolomic study using capillary electrophoresis-time of flight-mass spectrometry. J. Chromatogr. A 2008, 1195, 164-173. [CrossRef] [PubMed]

36. HaiBo, W.; Dachuan, L.; Yongming, L.; Haiying, W. Study on extracting and purifying isoflavones from soybean by hydrolysing. Food Sci. 2003, 24, 98-101.

37. Grynkiewicz, G.; Ksycinska, H.; Ramza, J.; Zagrodzka, J. Chromatographic quantification of isoflavones (why and how). Acta Chromatogr. 2005, 15, 31-64.

38. Müllner, C.; Sontag, G. Determination of some phytoestrogens in soybeans and their processed products with HPLC and coulometric electrode array detection. Fresenius J. Anal. Chem. 1999, 364, 261-265. [CrossRef]

39. Thompson, L.U.; Boucher, B.A.; Liu, Z.; Cotterchio, M.; Kreiger, N. Phytoestrogen content of food consumed in Canada, including isoflavones, lignans and coumestan. Nutr. Cancer 2006, 54, 184-201. [CrossRef] [PubMed]

(c) 2017 by the authors; licensee MDPI, Basel, Switzerland. This article is an open access article distributed under the terms and conditions of the Creative Commons Attribution (CC-BY) license (http://creativecommons.org/licenses/by/4.0/). 